\title{
Analisis Pemahaman Pajak dan Keadilan Pajak Terhadap Kepatuhan Wajib Pajak Usaha Mikro dan Kecil di Kota Palembang
}

\author{
Rizki Fitri Amalia \\ Politeknik Palcomtech, Palembang, Indonesia \\ rizki_fitri@palcomtech.ac.id
}

Corresponding Author : Rizki Fitri Amalia

Submitted: 2 Juni 2020

Accepted: 9 Agustus 2020

Published: 9 Agustus 2020

ABSTRAK

This study aims to determine whether the variable tax fairness and understanding of taxes can affect the taxpayer compliance of Micro and Small Enterprises in the city of Palembang. The theory used in this research is attribution theory. The population in this study were all Micro and Small Enterprises in the city of Palembang. The sampling technique uses purposive sampling. The data analysis technique used is multiple regression analysis used to determine the effect of tax fairness variables and understanding of taxes on tax compliance of Micro and Small Businesses in Palembang. The results obtained indicate that the tax fairness variable does not affect the taxpayer compliance of Micro and Small Enterprises in fulfilling the obligations of their tax, while understanding of taxes affects the taxpayer compliance of Micro and Small Enterprises in fulfilling the obligations of their tax.

Keywords: tax fairness, understanding of taxes, tax compliance, taxpayer

\section{PENDAHULUAN}

\subsection{Latar Belakang}

Perkembangan UMKM di Kota Palembang dari tahun ke tahun selalu meningkat. Dimana hingga memasuki pertengahan tahun 2019 setidaknya tercatat 37.000 UMKM terdapat di Kota Palembang. Hal ini menunjukkan bahwa potensi untuk meningkatkan jumlah penerimaan daerah melalui pajak di Kota Palembang dapat meningkat. Tetapi pada kenyataannya, penerimaan pajak dari UMKM tersebut belum optimal karena tidak sejalan dengan pertumbuhan UMKM yang terjadi. Hal inilah yang mendorong pemerintah untuk mengubah tarif pajak yang sebelumnya $1 \%$ menjadi
$0,5 \%$ yang tertuang dalam Peraturan Pemerintah No 23 Tahun 2018 dengan harapan dapat meningkatkan kepatuhan wajib pajak UMKM tersebut.

Peraturan Pemerintah Nomor 23 Tahun 2018 pada dasarnya mengatur pengenaan PPh Final Pasal 4 Ayat (2) bagi wajib pajak yang memiliki peredaran bruto (omset) sampai dengan 4,8 Miliar Rupiah dalam satu Tahun Pajak. Pokok perubahannya diantaranya adalah penurunan tarif $\mathrm{PPh}$ Final atas Penghasilan Bruto Tertentu dari semula $1 \%$ menjadi $0,5 \%$ dari omzet. PPh Final ini harus dibayarkan setiap bulan sebelum tanggal 15 bulan berikutnya dan tergantung dari besar kecilnya omset 
wajib pajak setiap bulan. Berbeda dengan Peraturan Pemerintah Nomor 46 Tahun 2013 yang tidak membatasi jangka waktu pengenaan tarif $\mathrm{PPh}$ Final, Peraturan Pemerintah Nomor 23 Tahun 2018 sudah mengatur mengenai jangka waktu pengenaan tarif $\mathrm{PPh}$ Final 0,5\% baik untuk Wajib Pajak Orang Pribadi Maupun Badan.

Peraturan ini kemudian direvisi dengan Peraturan Pemerntah Nomor 23 Tahun 2018 yang disahkan pada tanggal 8 Juni 2018, dimana tarif sebelumnya $1 \%$ kini diturunkan menjadi $0,5 \%$. Penurunan tarif ini tentunya diharapkan banyak masyarakat yang sebelumnya terbebani dengan tarif $1 \%$ kini merasa di peringan dengan tarif $0.5 \%$, sehingga hal ini nantinya akan meningkatkan penerimaan pajak negara. Bagi wajib pajak orang pribadi diberikan jangka waktu selama 7 tahun. Sementara bagi wajib pajak badan berbentuk koperasi, CV, dan Firma diberikan jangka waktu yang lebih singkat yaitu selama 4 tahun. Bagi wajib pajak badan yang berbentuk Perseroan Terbatas (PT) jangka waktunya paling singkat yaitu 3 tahun saja.

Direktorat Jenderal Pajak (Ditjen Pajak) Kementerian Keuangan mendorong Usaha Mikro, Kecil, Menengah (UMKM) untuk lebih sadar dan teredukasi mengenai perpajakan maupun pembukuan usaha. Upaya tersebut dituangkan melalui penandatanganan kerja sama dengan 27 instansi, yang terdiri dari 21 BUMN, Asosiasi Pengusaha Indonesia, Persatuan Perusahaan Real Estat Indonesia, hingga Lembaga Penyelidikan Ekonomi dan Masyarakat Fakultas Ekonomi dan Bisnis Universitas Indonesia (FEB UI). Direktur Jenderal Pajak Robert Pakpahan mengatakan, ruang lingkup perjanjian kerja sama ini mencakup pemberian pelatihan dan bimbingan terkait materi perpajakan, pembukuan, pencatatan, dan materi lainnya dalam program pembinaan UMKM yang dilakukan para instansi tersebut. Business Development Service (BDS) merupakan program terobosan Ditjen Pajak yang dijalankan sejak 2015 untuk pelayanan pembinaan kepada wajib pajak UMKM.

Program ini ditujukan untuk mendorong kemajuan usaha serta meningkatkan kesadaran dan kepatuhan pajak UMKM. Kerja sama dengan 27 instansi tersebut akan memperluas program BDS terhadap UMKM yang dibina oleh masing-masing instansi. Ditjen Pajak sebelumnya telah menandatangani perjanjian kerja sama serupa dengan bank-bank Himbara serta Telkom untuk pembinaan UMKM. Nantinya para mitra akan bersinergi dengan Kantor Wilayah DJP hingga KPP se-Indonesia dalam penerapan program DBS. Saat ini, UMKM yang terdaftar sebagai wajib pajak baru 1,8 juta dari puluhan juta. Sebagian dari mereka memang masih di bawah ambang batas pembayaran pajak. Namun, selebihnya masih banyak potensi pajak dari UMKM di Indonesia. Kerja sama ini diharapkan mampu membuat pelaku UMKM akan tumbuh lebih pesat dan semakin berdaya saing dengan kesadaran dan kepatuhan pajak yang tinggi Namun masih banyak wajib pajak UMKM yang kurang patuh membayar pajak karena beberapa faktor.

Faktor yang mempengaruhi kepatuhan wajib pajak dan pemahaman perpajakan. Menurut Siahaan (2010), Keadilan pajak adalah setiap wajib pajak menyumbangkan uang untuk pengeluaran pemerintah sebanding dengan kepentingannya dan manfaat yang diminta. Perpajakan yang adil adalah semakin besar penghasilan maka semakin besar pula pajak yang harus dibayar (the more you earn, the more you pay tax). Jalan menuju keadilan dalam perpajakan dimulai dari penentuan objeknya serta ukuran yang cukup jelas mengenai apa yang disebut sebagai kemampuan untuk membayar. Selain itu pemahaman perpajakan juga menjadi salah satu faktor 
yang mempengaruhi kepatuhan wajib pajak. Kurangnya pemahaman wajib pajak terhadap peraturan perpajakan cenderung akan menjadi tidak taat terhadap kewajiban Perpajakannya, tetapi jika wajib pajak paham terhadap peraturan perpajakan maka akan mendorong mereka untuk patuh terhadap kewajiban perpajakan (Julianti, 2015).

Menurut penelitian Agustiningsih, dkk (2016) yang menyimpulkan bahwa keadilan perpajakan berpengaruh positif terhadap kepatuhan wajib pajak. Namun hasil yang bertolak belakang dalam penelitian Averti dan Suryaputi (2019) yang menyimpulkan bahwa keadilan pajak tidak berpengaruh terhadap kepatuhan wajib pajak. Beberapa kajian yang mendukung penelitian ini yaitu Penelitian Suryadi (2016), variabel keadilan menunjukkan hubungan positif yang memengaruhi kepatuhan wajib pajak dan penelitian yang dilakukan Leo (2018) yang menemukan bahwa tingkat pemahaman wajib pajak berpengaruh positif terhadap kepatuhan wajib pajak.

\subsection{Rumusan Masalah}

Berdasarkan uraian latar belakang diatas dapat dirumuskan permasalahan yang ditemukan yaitu :

1. Bagaimana pengaruh keadilan pajak terhadap kepatuhan wajib pajak Usaha Mikro dan Kecil di Kota Palembang?

2. Bagaimana pengaruh pemahaman perpajakan terhadap kepatuhan wajib pajak Usaha Mikro dan Kecil di Kota Palembang?

\section{TINJAUAN PUSTAKA}

\subsection{Teori Atribusi}

Pada dasarnya, teori atribusi menyatakan bahwa bila individu-individu mengamati perilaku seseorang, mereka mencoba untuk menentukan apakah hal tersebut ditimbulkan secara internal atau eksternal (Robbins, 2006). Teori atribusi menjadi relevan untuk digunakan dalam penelitian ini adalah bahwa seseorang dalam menentukan perilaku patuh atau tidak patuh dalam memenuhi kewajiban perpajakannya dipengaruhi oleh faktor internal maupun eksternal. Faktor internal yang mempengaruhi kepatuhan wajib pajak antara lain: pemahaman pajak, sikap rasional, dan kondisi keuangan. Sedangkan, faktor eksternal yang mempengaruhi kepatuhan wajib pajak antara lain: kemudahan pajak dan keadilan pajak.

\subsection{Kepatuhan Wajib Pajak}

Menurut Arum (2012) mendefiniskan kepatuhan perpajakan sebagai suatu keadaan dimana wajib pajak memenuhi semua kewajiban perpajakan dan melaksanakan hak perpajakannya. Kepatuhan dalam hal perpajakan berarti keadaan wajib pajak yang melaksanakan hak, dan khususnya kewajibannya, secara disiplin, sesuai peraturan perundangundangan serta tata cara perpajakan yang berlaku. Kepatuhan wajib pajak didefinisikan sebagai kesadaran untuk memenuhi kewajibannya untuk mengisi formulir pajak dan menghitung sendiri jumlah pajak yang terutang dengan benar (Amalia, 2016). Berdasarkan keputusan Menteri Keuangan Nomor 192/PMK.03/2007 tentang tata cara penetapan wajib pajak, wajib pajak dapat ditetapkan sebagai wajib pajak patuh yang dapat diberikan pengembalian pendahuluan kelebihan pembayaran :

1. Tepat waktu dalam menyampaikan Surat Pemberitahuan (SPT) meliputi:

a. Menyampaikan SPT dalam 3 (tiga) tahun terakhir,

b. Dalam tahun terakhir penyampaian SPT Masa yang terlambat tidak lebih dari 3 (tiga) masa pajak untuk setiap jenis pajak dan berturut-turut,

c. SPT Masa yang terlambat itu disampaikan tidak lewat dari batas waktu penyampaian SPT Masa pajak berikutnya. 
2. Tidak mempunyai tunggakan pajak untuk semua jenis pajak pada tanggal 31 Desember tahun sebelum penetepan sebagai wajib pajak patuh;

a. Kecuali telah memperoleh izin untuk mengangsur atau menunda pembayaran pajak.

b. Tidak termasuk utang pajak yang belum melewati batas akhir pelunasan.

3. Laporan keuangan yang telah diaudit oleh akuntan publik atau lembaga pengawasan keuangan pemerintah dengan pendapat wajar tanpa pengecualian selama 3 (tiga) tahun berturut-turut harus:

a. Disusun dalam bentuk panjang (long form report)

b. Menyajikan rekonsiliasi laba rugi komersial dan fiskal bagi wajib pajak yang wajib menyampaikan SPT.

4. Tidak pernah dipidana karena melakukan tindak pidana dibanding perpajakan berdasarkan putusan pengadilan yang telah mempunyai kekuatan hokum tetap dalam jangka 5 (lima) tahun terakhir.

\subsection{Pengaruh Keadilan Pajak Terhadap Kepatuhan Wajib Pajak}

Keadilan pajak merupakan teori atribusi eksternal. Hal ini dikarenakan keadilan pajak timbul atau dilakukan karena adanya pengaruh eksternal atau dari luar individu tersebut. Keadilan pajak timbul karena wajib pajak merasa peraturan perpajakan dan sistem perpajakan yang dibuat oleh pemerintah belum adil sehingga mempengaruhi perilaku kepatuhan pajak mereka. Dan menurut teori fairness, dalam perpajakan keadilan mengacu pada pertukaran antara pembayar pajak dengan pemerintah, yaitu apa yang wajib pajak terima dari pemerintah atas sejumlah pajak yang telah dibayar. Jika wajib pajak merasa tidak mendapatkan pertukaran yang adil dari pemerintah atas pajak yang telah dibayarkannya, maka mereka akan mengubah pandangan mereka atas keadilan pajak sehingga berakibat pada perilaku mereka dalam membayar pajak dengan mengurangi beban pajak yang akan mereka bayarkan. Hal ini berarti bahwa semakin wajib pajak merasa tidak adil, maka mereka akan semakin tidak patuh.

H1:Keadilan pajak berpengaruh positif terhadap kepatuhan wajib pajak UMKM di Kota Palembang.

Pengaruh Pemahaman Perpajakan Terhadap Kepatuhan Wajib Pajak

Tingkat pemahaman wajib pajak atas perpajakan dapat diukur berdasarkan pemahaman wajib pajak pada kewajiban menghitung, membayar dan melaporkan pajak terutangnya. Semakin tinggi tingkat pengetahuan dan pemahaman wajib pajak terhadap peraturan perpajakan, maka semakin kecil kemungkinan wajib pajak untuk melanggar peraturan tersebut sehingga meningkatkan tingkat kepatuhan wajib pajak.

\section{H2:Pemahaman wajib pajak berpengaruh positif terhadap kepatuhan wajib pajak pemilik UMKM di Kota Palembang.}

\subsection{Kerangka Penelitian}

Penelitian ini akan menguji pengaruh sosialisasi perpajakan, sanksi perpajakan, dan mekanisme pembayaran pajak terhadap kepatuhan wajib pajak UMKM di kota Palembang

\begin{tabular}{|c|c|c|}
\hline $\begin{array}{c}\text { Keadilan Wajib Pajak } \\
\qquad\left(\mathrm{X}_{1}\right)\end{array}$ & $\mathrm{H}_{1}$ & $\begin{array}{l}\text { Kepatuhan } \\
\text { Waiib Pajak }\end{array}$ \\
\hline $\begin{array}{c}\text { Pemahaman } \\
\text { Perpajakan }\left(\mathrm{X}_{2}\right)\end{array}$ & $\mathrm{H}_{2}$ & $\begin{array}{l}\text { UMKM } \\
(\mathrm{Y})\end{array}$ \\
\hline
\end{tabular}

Gambar 2.1. Kerangka Pemikiran

\section{METODE PENELITIAN}

\subsection{Populasi}

Populasi dalam penelitian ini adalah seluruh Usaha Mikro dan Kecil di Kota Palembang. Dimana Usaha Mikro dan 
Kecil yang terdapat di Kota Palembang, dibawah binaan Dinas Koperasi Dan UKM Kota Palembang sekitar 4.000.

\subsection{Sampel}

Teknik pengambilan sampel pada penelitian ini menggunakan metode purposive sampling. Menurut Sugiyono (2011) pursposive sampling adalah teknik penentuan sampel dengan pertimbangan tertentu. Dalam penelitian ini, sampel yang diambil dari populasi yang menggunakan teknik purposive sampling didasarkan pada beberapa kriteria. Adapun kriteria pemilihan sampel dalam penelitian ini adalah:

1. Usaha Mikro dan Kecil yang berada di Kota Palembang dan berdiri lebih dari 1 tahun.

Hal ini dikarenakan Usaha Mikro dan Kecil yang berdiri kurang dari 1 tahun belum memiliki kewajiban apapun dalam pajak.

2. Memiliki omset per tahun dengan peredaran bruto tidak melebih dari Rp 4,8 miliar dalam 1(satu) Tahun Pajak.

Hal ini sesuai dengan Pajak Penghasilan sesuai Peraturan Pemerintah Nomor 23 Tahun 2018 tentang Usaha Mikro, Kecil, dan Menengah (UMKM) dalam cakupan usaha mikro dan kecil yang peneliti ambil dalam penelitian ini.

\subsection{Teknik Pengumpulan Data}

Teknik pengumpulan data dalam penelitian ini menggunakan teknik angket (kuesioner). Menurut Jogiyanto (2011), teknik pengumpulan data yang dilakukan dengan cara memberi seperangkat pertanyaan kepada responden untuk dijawabnya. Jenis kuesioner yang dipakai adalah kuesioner tertutup dimana dalam kuesioner ini, jawaban sudah disediakan oleh peneliti sehingga responden tinggal memilih saja mana jawaban yang sesuai dengan kebutuhan dalam riset

\subsection{Teknik Analisis Data}

Teknik analisis data dalam penelitian ini menggunakan analisis regresi linear berganda, yaitu untuk mengetahui besarnya pengaruh variabel independen terhadap variabel dependen. Teknik analisis regresi linear berganda dapat dirumuskan sebagai berikut:

$\mathrm{Y}=\mathrm{a}+\mathrm{b}_{1} \mathrm{x}_{1}+\mathrm{b}_{2} \mathrm{X}_{2}+\mathrm{b}_{3} \mathrm{x}_{3}+\mathrm{e}$

Keterangan:

$\mathrm{Y}=$ Kepatuhan wajib pajak UMKM

$\mathrm{a}=$ Konstanta

$\mathrm{x}_{1}=$ Keadilan Wajib Pajak

$\mathrm{b}=$ Koefisien regresi

$\mathrm{x}_{2}=$ Pemahaman Perpajakan

$\mathrm{e}=$ Standar error

\section{ANALISIS DAN PEMBAHASAN 4.1. Data Penelitian}

Peneliti menyebar sebanyak 60 kuesioner kepada 60 Usaha Mikro dan Kecil yang bergerak di kota Palembang. Penyebaran kuesioner dimulai dari tanggal 28 April 2020 sampai dengan 10 Mei 2020. Dari 60 kuesioner yang disebar oleh peneliti, terdapat 60 kuesioner yang dapat diolah. Selanjutnya hasil jawaban dari responden diukur dan diolah dengan menggunakan alat uji statistik berupa software, yaitu Statistical Package for Service Solution (SPSS) 21.

\subsection{Demografi Responden}

Analisis karakteristik responden bertujuan untuk memberikan gambaran mengenai identitas responden yang menjadi sampel. Analisis karakteristik responden pada penelitian ini adalah berdasarkan omzet dan kekayaan bersih per tahun. Berikut merupakan karakteristik responden dalam penelitian ini:

Tabel 4.1. Karakteristik Responden berdasarkan Omzet dan Kekayaan Bersih Per tahun

\begin{tabular}{ccc}
\hline Keterangan & Responden & Persentase \\
\hline Golongan Usaha & & \\
\hline
\end{tabular}




\begin{tabular}{rlcc}
\hline- & $\begin{array}{l}\text { Usaha } \\
\text { Mikro }\end{array}$ & 35 & $58,3 \%$ \\
\hline- & $\begin{array}{l}\text { Usaha } \\
\text { Kecil }\end{array}$ & 25 & $41,7 \%$ \\
\hline Total & & 60 & $100 \%$ \\
\hline
\end{tabular}

Sumber: Data yang diolah, 2020

Berdasarkan golongan usaha menunjukkan bahwa usaha mikro memilki penjualan per tahun maksimal $\mathrm{Rp}$ 300 juta yaitu 35 usaha mikro, kemudian sisanya sebanyak 25 responden merupakan usaha kecil. Dari hasil penyebaran kuesioner ini dapat diketahui bahwa yang menjadi responden adalah usaha mikro dan kemudian usaha kecil.

\subsection{Statistik Deskriptif}

Hasil analisis statistik deskriptif variabel-variabel yang digunakan dalam penelitian ini dapat dilihat melalui tabel sebagai berikut:

Tabel 4.2. Hasil Statistik Deskriptif

\begin{tabular}{|l|r|r|r|r|r|}
\hline & \multicolumn{1}{|c|}{ N } & \multicolumn{1}{c|}{ Min } & Max & Mean & Std. Dev \\
\hline Keadilan & 60 & 7.00 & 23.00 & 17.9833 & 3.70292 \\
\hline Pemahaman & 60 & 8.00 & 24.00 & 19.2333 & 2.91906 \\
\hline Kepatuhan & 60 & 10.00 & 25.00 & 19.8833 & 2.74999 \\
\hline
\end{tabular}

Sumber: Data yang diolah, 2020

Berdasarkan tabel 4.2 mengenai statistik deskriptif untuk variabel keadilan pajak dengan jumlah pernyataan 5 butir, dapat diketahui bahwa wajib pajak usaha mikro dan kecil rata-rata menjawab dengan nilai 17.98 yang berarti wajib pajak usaha mikro dan kecil cenderung netral sehingga setuju dengan pernyataanpernyataan yang ada dalam kuesioner.

\subsection{Uji Kualitas Instrumen Uji Validitas}

Tabel 4.3 Hasil Uji Validitas

\begin{tabular}{|c|c|c|c|c|}
\hline & $\begin{array}{l}\text { Nilai r- } \\
\text { Hitung }\end{array}$ & $\begin{array}{c}\text { Nilai } \mathbf{r}- \\
\text { Tabel }\end{array}$ & $\begin{array}{l}\text { Sig. } \\
(2- \\
\text { tailed })\end{array}$ & $\begin{array}{l}\text { Alpha untuk variabel sosialisasi } \\
\text { Kesimp perpajakan sebesar } 0,869 \text {. Nilai tersebut } \\
\text { ulan lebih besar dari } 0,60 \text {, maka butir-butir }\end{array}$ \\
\hline \multicolumn{4}{|c|}{ Variabel Keadilan Pajak } & iabel keadilan pajak d \\
\hline Pernyataan 1 & 0,840 & 0,259 & 0,000 & Valid \\
\hline
\end{tabular}

\begin{tabular}{|c|c|c|c|c|}
\hline Pernyataan 2 & 0.889 & 0,259 & 0,000 & Valid \\
\hline Pernyataan 3 & 0,806 & 0,259 & 0,000 & Valid \\
\hline Pernyataan 4 & 0,839 & 0,259 & 0,000 & Valid \\
\hline Pernyataan 5 & 0,698 & 0,259 & 0,000 & Valid \\
\hline \multicolumn{5}{|c|}{ Variabel Pemahaman Perpajakan } \\
\hline Pernyataan 1 & 0,836 & 0,259 & 0,000 & Valid \\
\hline Pernyataan 2 & 0,847 & 0,259 & 0,000 & Valid \\
\hline Pernyataan 3 & 0,866 & 0,259 & 0,000 & Valid \\
\hline Pernyataan 4 & 0,740 & 0,259 & 0,000 & Valid \\
\hline Pernyataan 5 & 0,784 & 0,259 & 0,000 & Valid \\
\hline \multicolumn{5}{|c|}{ Variabel Kepatuhan Wajib Pajak } \\
\hline Pernyataan 1 & 0,840 & 0,259 & 0,000 & Valid \\
\hline Pernyataan 2 & 0,889 & 0,259 & 0,000 & Valid \\
\hline Pernyataan 3 & 0,806 & 0,259 & 0,000 & Valid \\
\hline Pernyataan 4 & 0,839 & 0,259 & 0,000 & Valid \\
\hline Pernyataan 5 & 0,689 & 0,259 & 0,000 & Valid \\
\hline
\end{tabular}

Sumber : Data yang diolah, 2020

Berdasarkan Tabel 4.3 dapat dilihat bahwa setiap butir pernyataan dalam semua variabel lebih besar dari 0,259. Nilai 0,259 didapat dari $r$ tabel dengan jumlah responden $60(\mathrm{df}=\mathrm{n}-4)$ maka $\mathrm{df}=$ 56 dengan tingkat signifikansi 5\%. Maka, setiap butir pernyataan dalam semua variabel dinyatakan valid. Selain itu, valid atau tidaknya butir pernyataan dapat dilihat dari sig (2-tailed) dari variabel total. Apabila sig (2-tailed) $<0,05$ maka dinyatakan valid. Dari tabel 4.3 dapat dilihat bahwa setiap butir pernyataan dalam semua variabel memiliki sig (2tailed) < 0,05. Maka dari itu, setiap butir pernyataan dalam semua variabel dinyatakan valid.

\section{Uji Reliabilitas}

\section{Variabel Keadilan Pajak}

Tabel 4.4. Uji Reabilitas Variabel Keadilan Reliability Statistics

\begin{tabular}{|l|l|l|}
\hline $\begin{array}{l}\text { Cronbach's } \\
\text { Alpha }\end{array}$ & $\begin{array}{l}\text { Cronbach's Alpha } \\
\text { Based on } \\
\text { Standardized Items }\end{array}$ & $\begin{array}{l}\text { N of } \\
\text { Items }\end{array}$ \\
\hline .869 & .871 & 5 \\
\hline
\end{tabular}

Sumber: Data yang diolah, 2020

Berdasarkan tabel 4.4 nilai Cronbach's Alpha untuk variabel sosialisasi

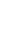

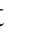


Variabel Pemahaman Perpajakan

Tabel 4.5 Uji Reabilitas Variabel

Pemahaman Perpajakan

Reliability Statistics

\begin{tabular}{|l|l|l|}
\hline $\begin{array}{l}\text { Cronbach's } \\
\text { Alpha }\end{array}$ & $\begin{array}{l}\text { Cronbach's Alpha } \\
\text { Based on } \\
\text { Standardized Items }\end{array}$ & N Items \\
\hline .871 & .873 & 5 \\
\hline
\end{tabular}

Sumber : Data yang diolah, 2020

Berdasarkan tabel 4.5 nilai Cronbach's Alpha untuk variabel sosialisasi perpajakan sebesar 0,871 . Nilai tersebut lebih besar dari 0,60, maka butir-butir pernyataan variabel pemahaman perpajakan dapat dinyatakan reliabel.

\section{Variabel Kepatuhan Wajib Pajak}

Tabel 4.6 Uji Reabilitas Variabel Kepatuhan Wajib Pajak

\begin{tabular}{|l|l|l|}
\hline \multicolumn{2}{|l|}{ Reliability Statistics } \\
\hline $\begin{array}{l}\text { Cronbach's } \\
\text { Alpha }\end{array}$ & $\begin{array}{l}\text { Cronbach's } \\
\text { Alpha Based on } \\
\text { Standardized } \\
\text { Items }\end{array}$ & N of Items \\
\hline .874 & .874 & 5 \\
\hline
\end{tabular}

Sumber : Data yang diolah, 2020

Berdasarkan tabel 4.6 nilai Cronbach's Alpha untuk variabel mekanisme pembayaran pajak sebesar 0,874 . Nilai tersebut lebih besar dari 0,600, maka butir-butir pernyataan variabel kepatuhan wajib pajak dinyatakan reliabel.

\section{Uji Normalitas}

Tabel 4.7. Uji Normalitas

One-Sample Kolmogorov-Smirnov Test Setelah Bootsraping

\begin{tabular}{|c|c|c|c|c|}
\hline \multicolumn{5}{|c|}{ Model Summary } \\
\hline Model & $R$ & $\begin{array}{c}R \\
\text { Square }\end{array}$ & $\begin{array}{l}\text { Adjusted } \\
R \text { Square }\end{array}$ & $\begin{array}{c}\text { Std. Error of } \\
\text { the Estimate }\end{array}$ \\
\hline 1 & $.796^{\mathrm{a}}$ & .634 & .621 & 1.69188 \\
\hline
\end{tabular}

a. Predictors: (Constant), PEMAHAMAN, KEADILAN

Sumber : Data yang diolah, 2020

Dapat dilihat bahwa hasil dari nilai Adjusted $R$ Square sebesar 621. Artinya seluruh variabel dalam penelitian ini baik keadilan, pemahaman mampu menjelaskan hubungannya sebesar 621 .

Tabel 4.8. Uji Normalitas

One-Sample Kolmogorov-Smirnov Test Setelah Bootsraping

\begin{tabular}{|c|c|c|c|c|c|}
\hline & & & & $\mathbf{V A}^{\mathrm{a}}$ & \\
\hline Model & $\begin{array}{l}\text { Sum of } \\
\text { Squares }\end{array}$ & $d f$ & $\begin{array}{l}\text { Mean } \\
\text { Square }\end{array}$ & $F$ & Sig. \\
\hline $\begin{array}{l}\text { Regre } \\
\text { ssion }\end{array}$ & 283.023 & 2 & 141.511 & 49.437 & $.000^{\mathrm{b}}$ \\
\hline $\begin{array}{c}\text { Residu } \\
\text { al }\end{array}$ & 163.160 & 57 & 2.862 & & \\
\hline Total & 446.183 & 59 & & & \\
\hline \multicolumn{6}{|c|}{ a. Dependent Variable: KEPATUHAN } \\
\hline \multicolumn{6}{|c|}{$\begin{array}{l}\text { b. Predictors: (Constant), PEMAHAMAN, } \\
\text { KEADILAN }\end{array}$} \\
\hline
\end{tabular}

Sumber : Data yang diolah, 2020

Dapat dilihat bahwa hasil dari nilai Sig. 0,000 yang berada dibawah minimal 0,05 . Artinya penelitian ini sangat layak untuk digunakan.

Tabel 4.9. Uji Normalitas One-Sample Kolmogorov-Smirnov Test

Setelah Bootsraping

\begin{tabular}{|c|c|c|c|c|c|}
\hline \multicolumn{6}{|c|}{ Bootstrap for Coefficients } \\
\hline \multirow[t]{3}{*}{ Model } & \multicolumn{5}{|c|}{ Bootstrap $^{a}$} \\
\hline & \multirow[t]{2}{*}{ Bias } & \multirow[t]{2}{*}{$\begin{array}{c}\text { Std. } \\
\text { Error }\end{array}$} & \multirow[t]{2}{*}{$\begin{array}{l}\text { Sig. }(2- \\
\text { tailed })\end{array}$} & \multicolumn{2}{|c|}{$\begin{array}{l}95 \% \text { Confidence } \\
\text { Interval }\end{array}$} \\
\hline & & & & Lower & Upper \\
\hline (Constant) & .126 & 1.705 & .004 & 2.462 & 9.483 \\
\hline Keadilan & .009 & .096 & .485 & -.093 & .278 \\
\hline Pemahaman & -.015 & .117 & .001 & .436 & .898 \\
\hline
\end{tabular}

Sumber : Data yang diolah, 2020

Dapat dilihat hasil dari nilai Sig. (2-tailed) di dalam variabel keadilan yaitu sebesar 0,485 yang berada dibawah minimal 0,05 yang artinya berpengaruh positif. Dan pada variabel pemahaman sebesar 0,001 yang berada dibawah minimal 0,05 yang artinya berpengaruh positif. 


\section{Pengujian Hipotesis}

Analisis Regresi Linear Berganda

Tabel 4.10. Hasil Uji Analisis Regresi Linear Berganda

\begin{tabular}{|c|c|c|c|c|c|}
\hline \multicolumn{6}{|c|}{ Coefficients $^{\mathbf{a}}$} \\
\hline \multirow[t]{2}{*}{ Model } & \multicolumn{2}{|c|}{$\begin{array}{l}\text { Unstandardiz } \\
\text { ed } \\
\text { Coefficients }\end{array}$} & \multirow{2}{*}{$\begin{array}{c}\text { Standar } \\
\text { dized } \\
\text { Coeffic } \\
\text { ients } \\
\text { Beta }\end{array}$} & \multirow[t]{2}{*}{$\mathrm{t}$} & \multirow[t]{2}{*}{ Sig. } \\
\hline & B & $\begin{array}{l}\text { Std. } \\
\text { Error }\end{array}$ & & & \\
\hline (Constant) & 631 & .228 & & 2.772 & .008 \\
\hline SQ_Keadilan & .114 & .102 & .142 & 1.111 & .271 \\
\hline $\begin{array}{l}\text { SQ_Pemaha } \\
\text { man }\end{array}$ & .617 & .136 & .579 & 4.531 & .000 \\
\hline
\end{tabular}

a. Dependent Variable: SQ_KEPATUHAN

Sumber : Data yang diolah, 2020

Berdasarkan hasil dari Tabel 4.10 dapat diperoleh persamaan regresi linear berganda sebagai berikut:

$\mathrm{Y}=0,631+0,114 \mathrm{X}_{1}+0,617 \mathrm{X}_{2}+\mathrm{e}$

Persamaan di atas dapat dijelaskan sebagai berikut:

a. Dari persamaan regresi tersebut nilai konstanta sebesar 0,631 secara sistematis menyatakan bahwa jika nilai variabel keadilan pajak, pehamaman perpajakan, sama dengan nol maka nilai y sebesar 0,631 .

b. Nilai koefisien regresi keadilan pajak sebesar 0,114 artinya jika variabel sosialisasi perpajakan ditingkatkan sebesar satu satuan, maka variabel keadilan pajak akan meningkat sebesar 0,114 satuan. Sebaliknya jika variabel keadilan pajak diturunkan satu satuan, maka pemahaman variabel keadilan pajak akan menurun sebesar 0,114.

c. Koefisien regresi pemahaman perpajakan sebesar 0,617 artinya jika variabel saksi perpajakan ditingkatkan sebesar satu satuan, maka variabel sanksi perpajakan akan meningkat sebesar 0,617 satuan. Sebaliknya jika variabel pemahaman perpajakan diturunkan satu satuan, maka pemahaman variabel pemahaman perpajakan akan menurun sebesar 0,617 .

\section{Koefisien Determinasi $\left(\mathbf{R}^{2}\right)$}

Tabel 4.11. Koefisien Determinasi $\left(\mathrm{R}^{2}\right)$

\begin{tabular}{|l|r|r|r|r|}
\multicolumn{5}{c|}{ Model Summary } \\
\hline Model & $R$ & $\begin{array}{c}R \\
\text { Square }\end{array}$ & $\begin{array}{l}\text { Adjusted } \\
R \text { Square }\end{array}$ & $\begin{array}{r}\text { Std. Error of } \\
\text { the Estimate }\end{array}$ \\
\hline 1 & $.680^{\mathrm{a}}$ & .462 & .443 & .53498 \\
\hline
\end{tabular}

a. Predictors: (Constant), SQ_PEMAHAMAN, SQ_KEADILAN

a. Predictors: (Constant), MPP_TOTAL, SA_TOTAL, SO_TOTAL

Sumber : Data yang diolah, 2020

Berdasarkan Tabel 4.11 menunjukkan nilai adjusted $R^{2}$ sebesar 0,443 yang berarti $44,3 \%$ tidak mampu menjelaskan kesinambungan kepatuhan pajak Usaha Mikro dan Kecil di kota Palembang oleh kedua variabel independen yaitu keadilan pajak dan pemahaman perpajakan. Sementara sisanya $55,7 \%$ dipengaruhi oleh variabel-variabel lain yang berada diluar penelitian ini.

\section{Uji Statistik F}

Tabel 4.12Uji Statistik F

$$
\text { ANOVA }^{\mathrm{a}}
$$

\begin{tabular}{|l|l|r|r|r|c|c|}
\hline \multicolumn{2}{|l|}{ Model } & $\begin{array}{c}\text { Sum of } \\
\text { Square }\end{array}$ & $d f$ & $\begin{array}{c}\text { Mean } \\
\text { Square }\end{array}$ & $F$ & Sig. \\
\hline \multirow{4}{*}{1} & $\begin{array}{l}\text { Regress } \\
\text { ion }\end{array}$ & 13.997 & 2 & 6.999 & 24.453 & $.000^{\mathrm{b}}$ \\
\cline { 2 - 7 } & $\begin{array}{l}\text { Residu } \\
\text { al }\end{array}$ & 16.314 & 57 & .286 & & \\
\cline { 2 - 7 } & Total & 30.311 & 59 & & & \\
\hline
\end{tabular}

a. Dependent Variable: SQ_KEPATUHAN

b. Predictors: (Constant), SQ_PEMAHAMAN, SQ_KEADILAN

Sumber : Data yang diolah, 2020

Dari tabel 4.12 didapat nilai $\mathrm{f}$ hitung sebesar 24.453 dengan signifikansi 0,000 karena signifikansi dibawah dari 0,05 , maka dapat dikatakan bahwa model 
penelitian ini sangat layak untuk digunakan.

\section{Uji Statistik T}

Tabel 4.13 Uji Statistik t

$$
\text { Coefficients }^{a}
$$

\begin{tabular}{|c|c|c|c|c|c|}
\hline \multirow[t]{2}{*}{ Model } & \multicolumn{2}{|c|}{$\begin{array}{l}\text { Unstandardize } \\
\text { d Coefficients }\end{array}$} & $\begin{array}{c}\text { Standardized } \\
\text { Coefficients }\end{array}$ & \multirow[t]{2}{*}{$\mathrm{t}$} & \multirow[t]{2}{*}{ Sig. } \\
\hline & B & $\begin{array}{l}\text { Std. } \\
\text { Error }\end{array}$ & Beta & & \\
\hline (Constant) & 631 & .228 & & 2.772 & .008 \\
\hline SQ_Keadilan & .114 & .102 & 142 & 1.111 & .271 \\
\hline SQ_Pemahaman & .617 & .136 & .579 & 4.531 & .000 \\
\hline
\end{tabular}

Sumber : Data yang diolah, 2020

Dari tabel 4.13 dapat diketahui bahwa variabel keadilan pajak, dan pemahaman perpajakan memiliki tingkat signifikansi 0,$271 ;, 000$ dibawah 0,05 . Sehingga dapat diartikan bahwa variabel keadilan pajak dan pemahaman perpajakan memiliki pengaruh terhadap kepatuhan wajib pajak usaha mikro dan kecil di kota Palembang secara signifikan.

\subsection{Pembahasan}

\section{Keadilan tidak berpengaruh terhadap Kepatuhan Wajib Pajak Usaha Mikro dan Kecil}

Uji t keadilan pajak menunjukkan tingkat signifikansi $0,271>0,05$. Berdasarkan hasil uji $\mathrm{t}$ tersebut, disimpulkan bahwa hipotesis (H1) yang berbunyi "keadilan pajak berpengaruh positif terhadap kepatuhan wajib pajak usaha mikro dan kecil di kota Palembang". ditolak yang berarti bahwa keadilan pajak tidak berpengaruh terhadap kepatuhan wajib pajak usaha mikro dan kecil.

Hasil penelitian ini sejalan dengan penelitian yang dilakukan oleh Raihan (2018) yang menyimpulkan bahwa keadilan pajak tidak berpengaruh terhadap kepatuhan wajib pajak. Jadi dapat disimpulkan bahwa walaupun semakin meningkatnya atau menurunnya keadilan pajak tidak akan mempengaruhi kepatuhan wajib pajak usaha mikro dan kecil. Hal ini memungkinkan adanya variabel lain di luar penelitian yang lebih berpengaruh terhadap kepatuhan wajib pajak UMKM.

\section{Pemahaman Perpajakan} berpengaruh terhadap Kepatuhan Wajib Pajak Usaha Mikro dan Kecil

Uji $t$ pemahaman perpajakan menunjukkan tingkat signifikansi $0,000<0,05$. Berdasarkan hasil uji $\mathrm{t}$ tersebut, disimpulkan bahwa hipotesis (H2) yang berbunyi "pemahaman perpajakan berpengaruh terhadap kepatuhan wajib pajak UMKM di kota Palembang“. diterima yang berarti Pemahaman perpajakan berpengaruh signifikan terhadap kepatuhan wajib pajak usaha mikro dan kecil. Dalam hal ini dikarenakan semakin wajib pajak paham terhadap peraturan perpajakan maka akan mendorong mereka untuk patuh terhadap kewajiban perpajakannya.

Hal ini sejalan dengan penelitian Farid Syahril (2012) yang menemukan bahwa tingkat pemahaman wajib pajak berpengaruh positif terhadap kepatuhan wajib pajak Jadi dapat disimpulkan bahwa walaupun semakin meningkatnya pemahaman perpajakan memiliki pengaruh signifikan terhadap kepatuhan wajib pajak usaha mikro dan kecil.

\section{KESIMPULAN}

Berdasarkan hasil penelitian dan pembahasan yang telah diuraikan sebelumnya, maka dapat ditarik beberapa kesimpulan yaitu:

1. Keadilan pajak tidak berpengaruh terhadap kepatuhan wajib pajak UMKM.

2. Pemahaman perpajakan berpengaruh terhadap kepatuhan wajib pajak UMKM secara signifikan.

Dengan adanya pemahaman akan pajak, diharapkan pelaku UMKM akan tumbuh 
lebih pesat dan semakin berdaya saing dengan kesadaran dan kepatuhan pajak yang tinggi

\section{Saran}

Berdasarkan hasil penelitian ini, peneliti dapat memberikan saran sebagai berikut:

1. Penelitian selanjutnya dapat menambah jumlah responden lebih banyak agar hasil penelitian dapat lebih relevan dan layak.

2. Diharapkan peneliti selanjutnya agar dapat menambah variabel-variabel lain untuk mengukur kepatuhan wajib pajak usaha mikro dan kecil.

\section{REFERENCES}

Amalia, Rizki Fitri. (2016). Pengaruh Penerapan e-Filing Terhadap Tingkat Kepatuhan Penyampaian SPT Tahunan Pajak Penghasilan Wajib Pajak Orang Pribadi dengan Pelayanan Account Representative sebagai Variabel Intervening Di Kota Palembang. Jurnal Ilmiah Orasi Bisnis - Volume 15 Bulan Mei. ISSN 2085- 1375.

Agustiningsih, Wulandari dan Isroah. (2016). Pengaruh Penerapan E-Filing, Tingkat Pemahaman Perpajakan dan Kesadaran Wajib Pajak Terhadap Kepatuhan Wajib Pajak Di KPP Pratama Yogyakarta. Jurnal Economia. Universitas Negeri Yogyakarta.

Arum, Harjanti Puspa. (2012) Pengaruh Kesadaran WP, Pelayanan Fiskus dan Sanksi Pajak Terhadap Kepatuhan WP OP yang melakukan Kegiatan Usan dan Pekerjaan Bebas. Jurnal Volume 1, Nomor 1, Halaman $1-8$. Averti dan Suryaputi. (2019). Pengaruh Keadilan Perpajakan, Sistem Perpajakan, Diskriminasi Perpajakan, Kepatuhan Wajib Pajak Terhadap Penggelapan

Jogiyanto, H.M. (2011). Metodologi Penelitian Bisnis.Edisi Keempat. BPFE. Yogyakarta.
Julianti, Murni. (2015). Analisis FaktorFaktor yang Mempengaruhi KepatuhanWajib Pajak Orang Pribadi Untuk Membayar Pajak Dengan Kondisi Keuangan dan Preferensi Risiko Wajib Pajak SebagaiVariabel Moderating. Universitas Diponegoro.

Leo, Armadus. (2018). Pengaruh Tingkat Pemahaman Wajib pajak, Sanksi Pajak dan Kualitas Pelayanan Fiskus Terhadap Tingkat Kepatuhan Wajib Pajak Kendaraan Bermotor di Kota Pontianak. Jurnal Kajian Ilmiah Akuntansi Fakultas Ekonomi UNTAN (KIAFE). Volume 7. Nomor 2.

Robbins, P. Stephen. (2006). Perilaku Organisasi. Edisi Sepuluh. Diterjemahkan oleh: Drs. Benyamin Molan. Erlangga, Jakarta.

Siahaan, Marihot P. (2010). Hukum Pajak Material. Yogyakarta : Penerbit Graha Ilmu.

Suryadi, Dedi. (2016). Pengaruh Dimensi Keadilan Pajak dan Tax Morale Terhadap Tingkat Kepatuhan Wajib Pajak Badan yang Terdaftar di KPP Pratama Kota Bandung. TEDC Vol.10 No.1 Januari: 61-69.

Sugiyono. (2013). Metode Penelitian Pendidikan (Pendekatan Kuantitati, Kualitatif, dan R\&D). Alfabeta. Bandung.

\section{Peraturan:}

Peraturan Pemerintah (PP) Nomor 23 Tahun 2018 tentang Pajak Penghasilan atas Penghasilan Dari Usaha yang Diterima atau Diperoleh Wajib Pajak yang Memiliki Peredaran Bruto Tertentu.

Peraturan Pemerintah Republik Indonesia Nomor 46 Tahun 2013 Tentang Pajak Penghasilan Atas Penghasilan Dari Usaha yang Diterima Atau Diperoleh Wajib Pajak yang Memiliki Peredaran Bruto Tertentu. 
